University of New Hampshire

University of New Hampshire Scholars' Repository

Law Faculty Scholarship

University of New Hampshire - Franklin Pierce

School of Law

2019

\title{
3D Printing and U.S. Copyright Law
}

Ryan G. Vacca

University of New Hampshire Franklin Pierce School of Law, ryan.vacca@law.unh.edu

Peter S. Menell

University of California, Berkeley - School of Law

Follow this and additional works at: https://scholars.unh.edu/law_facpub

Part of the Intellectual Property Law Commons

Comments

This is a preprint version.

\section{Recommended Citation}

preprint - U.S. Copyright Law and 3D Printing, in 3D PRINTING AND BEYOND: THE INTELLECTUAL PROPERTY AND LEGAL AND IMPLICATIONS SURROUNDING 3D PRINTING AND EMERGING TECHNOLOGIES (D. Mendis, M. Lemley, \& M. Rimmer, eds. Edward Elgar Publishing) (2019) (with P. Menell)

This Book Chapter is brought to you for free and open access by the University of New Hampshire - Franklin Pierce School of Law at University of New Hampshire Scholars' Repository. It has been accepted for inclusion in Law Faculty Scholarship by an authorized administrator of University of New Hampshire Scholars' Repository. For more information, please contact sue.zago@law.unh.edu. 


\title{
3D Printing and US Copyright Law
}

\author{
Peter S. Menell ${ }^{*} \&$ Ryan Vacca**
}

The emergence of 3D printing - the use of computer-aided design (CAD) files ${ }^{1}$ with threedimensional deposition, extrusion, and sintering devices-has opened a new front in the digital revolution. Designers can now manufacture objects directly from computer software using increasingly available and versatile 3D printing devices. This new and expanding functionality promises to enhance creativity and reduce costs across a wide range of industries. 3D printing is now being used to "print" toys, apparel, machine parts, medical devices, body parts, drugs, firearms, and even entire buildings.

3D printing has opened up new distribution channels for design, print-on-demand aftermarkets, and customizable product lines. Businesses no longer need to stock large inventories of parts. Consumers now have the ability to download or scan and reconstruct a broken component for a household appliance in their home.

Nevertheless, with these opportunities come risks and challenges. Designs and CAD files, like any other digital files, can be easily reproduced and disseminated without authorization. Product manufacturers are seeing new competition for replacement parts by a new layer of "after-market" competitors. Designers are seeing their work product scanned and disseminated without authorization. All manner of physical goods are being "Napsterized" ${ }^{2}$ in the 3D printing revolution. The potential applications of 3D printing, as well as the intellectual property and broader legal ramifications, are wide-ranging and only beginning to come into focus.

This article explores how 3D printing fits within US copyright law. US copyright law provides a well-developed general framework for the protection of creative designs, whether fixed in CAD files or 3D objects. Enforcement of copyright protection in this industry faces some of the same challenges encountered by other content industries whose works were disrupted by the digital revolution. Nonetheless, 3D printing brings distinctive issues. Although grounded in statute, US copyright law has a rich common law tradition that affords courts significant leeway in adapting doctrines to new and unforeseen technological developments. ${ }^{3}$ This capacity is reinforced by the range of business strategies available for confronting appropriability challenges. Thus, this article surveys the 3D printing terrain on three levels: (I) copyrightability of CAD files and 3D objects; (II) enforcement challenges; and (III) business strategies.

\footnotetext{
* Koret Professor of Law and Director, Berkeley Center for Law \& Technology, University of California at Berkeley School of Law.

** Interim Co-Dean, David L. Brennan Professor of Law, and Director of the Center for Intellectual Property Law \& Technology, University of Akron School of Law.

The authors thank Will Buckingham and Bill Ryan for their excellent research assistance.

${ }^{1}$ Although there are a variety of file types associated with 3D printing, such as STL and VRML, we use the term CAD to refer to all the file formats.

2 See Raymond Shih Ray Ku, The Creative Destruction of Copyright: Napster and the New Economics of Digital Technology, 69 U. CHI. L. REV. 263 (2002); see also Deven R. Desai \& Gerard N. Magliocca, Patents, Meet Napster: 3D Printing and the Digitization of Things, 102 GEORGETOWN L.J. 1691 (2014).

${ }^{3}$ See Peter S. Menell, The Mixed Heritage of Federal Intellectual Property Law and Ramifications for Statutory Interpretation, in INTELlECTUAL PROPERTY AND THE COMMON LAW 63 (Shyamkrishna Balganesh ed., 2013).
} 


\section{Copyrightability}

US copyright law has long protected graphical and sculptural works. ${ }^{4}$ Its originality threshold, idea-expression doctrine, and useful article doctrine come into play in addressing the copyrightability of CAD files and objects.

\section{A. Originality}

Section 102(a) of the Copyright Act extends copyright protection to "original works of authorship fixed in any tangible medium of expression." The originality threshold requires only that a work be independently created ${ }^{5}$ and reflect a modicum of originality. ${ }^{6}$ The statute does not require "novelty, ingenuity, or esthetic merit."7

Thus, independently created ornamental designs and three-dimensional sculptures, fixed in CAD files or physical objects, generally qualify for copyright protection. ${ }^{8}$ The originality threshold can come into play where a designer merely scans an existing object or design, such as a toy. While faithful imaging may require substantial effort and skill, copyright protection does not extend to such "sweat of the brow." "9 There must be creative effort. Thus, the Tenth Circuit held in Meshwerks Inc. v. Toyota Motor Sales USA, Inc. ${ }^{10}$ that the creation of an exact digital replica of an automobile chassis lacked sufficient creativity to garner copyright protection.

Although copyright law affords protection for "derivative works," ${ }^{11}$ subsequent creators must bring forth more than trivial variation from the existing works. In L. Batlin \& Sons, Inc. v. Snyder, the Second Circuit held that a plastic version of a public domain metal Uncle Sam bank did not constitute sufficient originality because the only changes were in the size and material of the bank, as well as the shape of the satchel and the substitution of leaves for arrows in the eagle's talons. ${ }^{12}$ These minor changes to the public domain work were too trivial to entitle the derivative work to copyright protection.

Furthermore, "protection for a work employing preexisting material [such as a sculptural work created by another] does not extend to any part of the work in which such materials has been used unlawfully." 13 Thus, a CAD file that faithfully reproduces a copyright-protected sculptural work is not protectable unless done by the copyright owner of the underlying work or with that artist's authorization.

\section{B. Functionality and the Useful Article Doctrine}

\footnotetext{
${ }^{4}$ See Act of July 8, 1870, ch. 230, §§85-111, 16 Stat. 198, 212-16.

${ }^{5}$ Sheldon v. Metro-Goldwyn Pictures Corp., 81 F.2d 49, 54 (2d Cir. 1936).

${ }^{6}$ Feist Publications v. Rural Telephone Service, 499 U.S. 340 (1991).

${ }^{7}$ See H.R. REP. NO. 94-1476, at 52 (1976).

${ }^{8}$ See Edward Lee, Digital Originality, 14 VAND. J. ENT. \& TECH. L. 919, 949-950 (2012).

9 See Feist Publications v. Rural Telephone Service, 499 U.S. 340 (1991); Desai \& Magliocca, supra note 2, at 170607.

10528 F.3d 1258, 1269-70 (10th Cir. 2008).

11 “A 'derivative work' is a work based upon one or more preexisting works, such as a translation, musical arrangement, dramatization, fictionalization, motion picture version, sound recording, art reproduction, abridgment, condensation, or any other form in which a work may be recast, transformed, or adapted. A work consisting of editorial revisions, annotations, elaborations, or other modifications which, as a whole, represent an original work of authorship, is a ‘derivative work'.” 17 U.S.C. $\$ 101$ (definition of “derivative work”).

12 L. Batlin \& Son, Inc. v. Snyder, 536 F.2d 486, 489 (2nd Cir. 1976).

1317 U.S.C. $\$ 103(a)$.
} 
Copyright law's exclusion of protection for functional aspects of works of authorship erects a more significant barrier to copyrightability of CAD files and three-dimensional objects. Section 102(b) bars protection for any "idea, procedure, process, system, method of operation, concept, principle, or discovery, regardless of the form in which it is described, explained, illustrated, or embodied in such work."

Furthermore, although copyright protection extends to pictorial, graphic, and sculptural works” (PGS works), ${ }^{14}$ the useful article doctrine excludes protection for those aspects of a PGS work that cannot "be identified separately from, and are capable of existing independently of, the utilitarian aspects of the article." 15 The House Report accompanying the Copyright Act refers to both physical and conceptual separability. ${ }^{16}$

An expressive element of a useful article is physically separable if it can stand alone from the article as a whole "by ordinary means while leaving the utilitarian aspects of the article completely intact." ${ }^{17}$ For example, Jaguar's iconic leaping cat hood ornament is physically separable from the car because it can be physically removed from the car without impairing the ability to drive the vehicle. Thus, decorative sculptural features reflected in a CAD file or a 3D printed object are eligible for copyright protection if they can be physically separated from the utilitarian features of a depicted or physical design.

More difficult separability issues arise when form and function are tightly integrated, as, for example, in Apple's iPod products. In Brandir International, Inc. v. Cascade Pacific Lumber Co., ${ }^{18}$ a case involving the now iconic ribbon bicycle rack, the Second Circuit adopted a test that focuses on the designer's intent: "if design elements reflect a merger of aesthetic and functional considerations, the artistic aspects of a work cannot be said to be conceptually separable from the utilitarian elements. Conversely, where design elements can be identified as reflecting the designer's artistic judgment exercised independently of functional influences, conceptual separability exists." ${ }^{19}$ Professor Paul Goldstein has suggested the following formulation: “[A] pictorial, graphic or sculptural feature incorporated in the design of a useful article is conceptually separable if it can stand on its own as a work of art traditionally conceived, and if the useful article in which it is embodied would be equally useful without it." 20 The courts, however, have struggled to develop a uniform, straightforward test for conceptual separability. ${ }^{21}$

The myriad tests for conceptual separability pose a problem for 3D printing. ${ }^{22}$ Many 3D printing designs combine aesthetic and functional features. The lack of a single, easy-to-apply test for conceptual separability exacerbates the uncertainty surrounding copyright protection and infringement for the 3D printing industry.

1417 U.S.C. \$102(a)(5) (a "two-dimensional and three-dimensional works of fine, graphic, and applied art, photographs, prints and art reproductions, maps, globes, charts, diagrams, models, and technical drawings, including architectural plans”).

${ }^{15}$ See id. (limiting the scope of protection for PGS works).

${ }^{16}$ See H.R. REP. 94-1476, at 55 (1976).

${ }^{17}$ U.S. Copyright Office, Compendium of U.S. Copyright OfFice Practices §924.2(A) (3rd ed. 2014); Esquire, Inc. v. Ringer, 591 F.2d 796 (D.C. Cir. 1978).

18834 F.2d 1142 (2d Cir. 1987).

${ }^{19} \mathrm{Id}$. at 1145.

${ }^{20}$ See PAUL GOLDSTEIN, COPYRIGHT §2.5.3.1.

${ }^{21}$ See Varsity Brands, Inc. v. Star Athletica, LLC, 799 F.3d 468, 496-497 (6th Cir. 2015) (McKeague, J., dissenting) (observing that "[t]he law in this area is a mess-and it has been for a long time"), cert. granted, 136 S.Ct. 1823 (2016).

${ }^{22}$ Brief of Amici Curiae FormLabs Inc., Matter and Form, Inc., and Shapeways, Inc. in Support of Petitioner at 2-4, Star Athletica v. Varsity Brands, Inc., No. 15-866 (Feb. 8, 2016), 2016 U.S. S. Ct. Briefs LEXIS 628. 
The Copyright Act limits the owner of copyright in a CAD file that captures a sculptural work in the public domain or created by someone else "to the expressive creativity contributed by the CAD file author, as distinguished from the preexisting material employed in the work, and does not imply any exclusive right in the preexisting material." 23 Thus, the maker of a CAD file that merely portrays a pre-existing sculptural work designed by someone else does not thereby acquire any rights in the design. CAD files are essentially digital versions of technical drawings. ${ }^{24}$ As a result, if someone creates a CAD file for printing a useful article designed by another person, such as a prosthetic limb, the creator of the CAD file would be unable to prevent anyone else from recreating the prosthetic limb. ${ }^{25}$ That said, the copyright owner of the CAD file might have a valid copyright in the computer software file itself. Therefore, the CAD file owner might still enforce its copyright against those who reproduce and distribute the CAD file, although even that copyright could be invalid if created without authorization. ${ }^{26}$ As the next section explores, the owner of that file faces legal and practical challenges enforcing its copyright.

\section{Enforcement Challenges}

The ease with which sculptural works can be scanned into digital files that can be easily and anonymously shared through cyberspace in conjunction with the growing availability of 3D printing devices has opened up the potential for widespread unauthorized reproduction and distribution of designs. Like the music industry following the emergence of Internet file-sharing, ${ }^{27}$ the design industry faces a growing threat to copyright protection of its creative works. Nonetheless, the broad range of design markets (from sophisticated high technology products to high art sculptures and simple figurines and toys), the limited protection for useful articles, and various other distinctive factors suggest that $3 \mathrm{D}$ printing will blaze new trails for copyright enforcement and business strategy.

The problem of online infringement can usefully be characterizing as a layered pyramid, with the top of the pyramid representing core Internet functionality (the backbone providers). Computer, printer, and other hardware manufacturers represent the next layer, followed by Internet Service Providers and software application vendors (such as search engines and websites). End users populate the wide base of the pyramid. Copyright owners face a daunting series of practical and legal complexities in choosing how to target copyright infringement within this hierarchy. Decapitating the pyramid provides a simple, but vastly over-inclusive, solution. Society loses the vast non-infringing uses and communication capabilities of the Internet. The Sony staple article of commerce doctrine ${ }^{28}$ and the $§ 512$ Online Service Provider safe harbor ${ }^{29}$ limit the indirect liability of vendors and service providers in the middle and top layers of the pyramid. Yet going after the lowest level of the pyramid - the file-sharers - poses a vast scalability challenge. New sources of infringement spring up faster than existing sources can be taken down. Since indirect liability

2317 U.S.C. §103(b).

${ }^{24}$ Frank Ward, Patents \& 3D Printing: Protecting the Democratization of Manufacturing by Combining Existing Intellectual Property Protections, 25 DePAul J. ART, TECH. \& INTELL. Prop. L. 91, 110, 114, 124 (2014).

25 The CAD file would constitute a derivative work. Under 17 U.S.C. §106(2), the author of such CAD file would need authorization from the owner of copyright in the sculptural work.

${ }^{26}$ See 17 U.S.C. $\S 103(\mathrm{a})$.

27 See generally Peter S. Menell, Envisioning Copyright Law's Digital Future, 46 N.Y.L. SCH. L. REV. 63, 98-199 (2002-2003).

${ }^{28}$ See Sony Corporation of America v. Universal City Studios, Inc., 464 U.S. 417 (1984).

${ }^{29}$ See 17 U.S.C. §512. 
requires an underlying finding of direct infringement, we will work our way up through the digital liability pyramid from the bottom. It will be useful to examine several practical and procedural issues before turning to direct and indirect copyright liability.

\section{A. Threshold Enforcement Issues}

The architecture of the Internet and other digital distribution platforms presents substantial challenges for copyright owners. Detecting sources of infringement can be often be difficult, especially when works are shared through covert networks and complex file-sharing systems such as Bittorrent. And even where infringements or possible infringements can be identified through general Internet searches, the website owners might not be easily identified. Copyright owners might need to file a lawsuit to pursue discovery of website owners. Furthermore, the websites might be controlled outside of the reach of US courts, requiring copyright owners to pursue violations through foreign legal systems.

Even when the file-sharer can be pursued in court, the amount of recovery might not justify the enforcement costs. Although US copyright law authorizes a broad arsenal of remedies, ${ }^{30}$ including injunctive relief and statutory damages of up to $\$ 150,000$ per work infringed for willful infringement, the practical reality is that shutting down individual file-sharers will likely have little discernible effect on the availability of copies of files on the Internet. ${ }^{31}$ Moreover, judges are reluctant to impose crushing liability on non-commercial file-sharers. ${ }^{32}$ And even when they do, the defendants may well be judgment-proof. Moreover, overly punitive enforcement against filesharers can contribute to pathological social norms that fuel infringement. ${ }^{33}$ The government can also pursue criminal enforcement actions for willful infringement, ${ }^{34}$ although such small-scale activity does not rank high on prosecutor's priority list.

There are, however, several distinctions between music file-sharing and CAD file sharing that point toward more robust private and public copyright enforcement. 3D printing could pull largerscale commercial enterprises into file-sharing. File-sharing of valuable replacement parts could well be worth pursuing by original developers of those products. Such file-sharing could have significant financial effects and, to the extent that the CAD files are flawed or the instructions are inaccurate, could threaten the reputation of the original source. Furthermore, the government could take a greater interest in pursuing some entrants, ${ }^{35}$ especially where the products affect public health or safety.

\footnotetext{
3017 U.S.C. $§ 502-505$.

31 See Ben Depoorter, Intellectual Property Infringements \& 3D Printing: Decentralized Piracy, 65 HASTINGs L.J. 1483, 1496-97 (2014).

32 See Peter S. Menell, This American Copyright Life: Reflections on Re-Equilibrating Copyright for the Internet Age, 61 J. COPYRIGHT SoC’y U.S.A. 235, 263-64 (2014); Sony BMG Music Entm’t v. Tenenbaum, 672 F. Supp. 2d 217, 237 (D. Mass. 2009).

33 See Ben Depoorter, Alain Van Hiel, \& Sven Vanneste, Copyright Backlash, 84 S. CAL. L. REV. 1251 (2011).

3417 U.S.C. $\S 506$.

35 Note that the government pursued the operators of MegaUpload, a large, commercial cyber-locker enterprise that contributed significantly to the level of file-sharing of entertainment industry works. See NATE ANDERSON, THE INTERNET POLICE: HOW CRIME WENT ONLINE, AND THE COPS FOLLOWED 199-202 (2013); $c f$. U.S. INTELLECTUAL PROPERTY ENFORCEMENT COORDINATOR, 2012 U.S. INTELLECTUAL PROPERTY ENFORCEMENT COORDINATOR JOINT STRATEGIC PLAN 1 (June 2012), https://www.whitehouse.gov/sites/default/files/omb/IPEC/ipec_twoyear_anniversary_report.pdf. Similarly, several foreign governments have pursued the operators of The Pirate Bay. See Stephen Bright, Current Development, The Current State of BitTorrent in International Law: Why Copyright Law is Ineffective and What Needs to Change, 17 NEW ENG. J. INT'L \& COMP. L. 265, 266 (2011).
} 


\section{B. Direct Liability}

Assuming copyright protection subsists in a CAD file or other digital instantiations of a sculptural work based on the considerations canvassed in Part I, the copyright owner would be able to pursue those who reproduce literal or substantially similar copies of the copyrighted work without authorization subject to various statutory and doctrinal limitations, such as fair use. The copyright owner would also be able to pursue violations of the right to prepare derivative works for unauthorized adaptations of the copyrighted work, the right to distribute the copyrighted work by transmitting the copyrighted work (or possibly merely making the work available), and the right to display the work publicly (for example by posting images of the design on a website).

\section{Reproduction Right}

Section 106(1) imposes liability on those who reproduce copyrighted works without authorization, subject to the fair use privilege or defense and a variety of other limitations and compulsory licenses that are unlikely to apply to CAD file reproduction. The right to reproduce granted by $\$ 106(1)$ is not limited to literal reproduction. Rather, it protects against the unauthorized making of "substantially similar" reproductions of protected expression.

To prove a violation of the reproduction right, US copyright law requires the copyright owner to establish actual copying of protected expression resulting in substantial similarity. Thus, independent creation is a complete defense. Furthermore, the exclusion of unoriginal and functional features of useful articles and computer software limit the range of protected expression in a work. Others are free to copy those features, although it is important to recognize that original selections and arrangements of even unprotected features can attract copyright protection as compilations. Such compilations, however, are entitled to only thin protection. ${ }^{36}$

Nonetheless, the wholesale reproduction of CAD files or the printing of the entirety of even thinly protected objects will, in most cases, violate the reproduction right. ${ }^{37}$ The act of downloading and storing a CAD file in the computer memory of a 3D printer constitutes a reproduction of a copyrighted work. ${ }^{38}$ Similarly, companies such as Shapeways, which print usersubmitted designs and then ship the product to the customer, face liability for infringing the reproduction right.

US copyright law has long recognized a fair use privilege or defense. The doctrine originated in jurisprudence, ${ }^{39}$ and was codified in the Copyright Act of 1976. Section 107 provides several factors to balance in determining whether a use is fair. ${ }^{40}$ The legislative history notes that

\footnotetext{
${ }^{36}$ Courts require "virtual identity" or "bodily appropriation" to find infringement of such works. See Mattel, Inc. v. MGA Entertainment, Inc., 616 F.3d 904, 914-15 (9th Cir. 2010); Incredible Technologies, Inc. v. Virtual Technologies, 400 F.3d 1007 (7th Cir. 2005).

${ }^{37}$ Haritha Dasari, Note, Assessing Copyright Protection and Infringement Issues Involved with 3D Printing and Scanning, 41 AIPLA QUARTERLY JouRNAL 279, 306-307 (2013); Ben Depoorter, Intellectual Property Infringements \& 3D Printing: Decentralized Piracy, 65 HASTINGS L.J. 1483, 1488 (2014).

${ }^{38}$ See Eli Greenbaum, Three-Dimensional Printing and Open-Source Hardware, 2 NYU J. INTELL. PROP. \& ENT. L. 257, 276 (2013).

${ }^{39}$ See Whittemore v. Cutter, 29 Fed. Cas. 1120 (C.C.D. Mass. 1813).

${ }^{40} 17$ U.S.C. $\S 107$.
} 
"courts must be free to adapt the doctrine to particular situations on a case-by-case basis" "especially during a period of rapid technological change." 41

Courts have long considered the commerciality of the use-particularly the effect on the potential market for the copyrighted work - to be of prime significance. ${ }^{42}$ Courts increasingly emphasize the "transformativeness" of the use, which focuses on the extent to which the defendant's use is productive, employs the protected work in a different manner or purpose, or brings new information, aesthetics, insights, or understandings. ${ }^{43}$

Lacking some educational or research purpose, direct reproduction of CAD files and underlying copyrighted works are unlikely to benefit from the fair use doctrine. The fair use doctrine is more likely to come into play in the context of adaptations of such works.

\section{Derivative Work Right}

Section 106(2) grants "copyright owners the exclusive right to prepare derivative works based upon the copyrighted work." Thus, a photograph or scan of copyrighted two- or three-dimensional work implicates the derivative work or adaptation right. The statute defines a derivative work as "a work based upon one or more preexisting works. . . A work consisting of editorial revisions, annotations, elaborations, or other modifications which, as a whole, represent an original work of authorship, is a 'derivative work." 44

The test for infringement of the derivative work right parallels the test for infringement of the reproduction right. Courts assess whether the defendant's work copies the copyrighted work to such an extent that there is substantial similarity of protected expression. Thus, faithfully scanning a copyrighted object infringes copyright in that sculptural work. Likewise, those who download and modify CAD files likely violate the adaptation right, as well as those who subsequently print the modified product.

While those who modify a copyrighted CAD file or object fall within the ambit of the $\S 106(2)$ right, they may nonetheless qualify for the fair use privilege to the extent their adaptation transforms the underlying work in a sufficiently productive way. Innovations in digital technology have democratized the ability for users and consumers to adapt existing works in innovative ways. $^{45}$

\section{Distribution Right}

Section 106(3) grants copyright owners the "exclusive right to do and to authorize" the following: "to distribute copies or phonorecords of the copyrighted work to the public by sale or other transfer of ownership, or by rental, lease, or lending." This right grows out of the historic rights "to publish" and "to vend" recognized by earlier copyright statutes. It is closely allied with the right to copy, since reproduction has been the principal means of exploiting works of authorship for most of copyright's history. Thus, copying and selling a copyright owner's work without authorization violates both the right to copy and the right to distribute. As a corollary, both the

\footnotetext{
${ }^{41}$ See H.R. REP. 94-1476 at 66 (1976).

42 See Harper \& Row Publishers, Inc. v. Nation Enterprises, 471 U.S. 539, 566 (1985).

43 See Campbell v. Acuff-Rose Music, Inc., 510 U.S. 569, 579 (1994); Pierre N. Leval, Toward A Fair Use Standard, 103 HARV. L. REV. 1105 (1990).

4417 U.S.C. $\S 101$ (2016).

45 See ERIC VON HipPEL, DEMOCRATIZING INNOVATION (2006).
} 
copier who never does anything with his or her copies and the unknowing distributor of unauthorized copies are liable for copyright infringement. Section 602 of the Copyright Act augments the distribution right by affording copyright owners the right to block importation or exportation of copies, subject to limited exceptions. ${ }^{46}$

Prior to the emergence of file-sharing technology, the Copyright Act's distribution right was largely dormant as most enforcement actions were premised upon violations of the reproduction right. With the proliferation of files-sharing over the Internet, direct enforcement of the Copyright Act against file-sharers has brought the scope of the distribution right to center stage because many individual defendants are charged with allowing access to shared folders containing copyrighted files. Reproduction occurs through download of files by others.

The ramifications for copyright enforcement in the Internet age are substantial. Under the narrow interpretation, the relative anonymity of Internet transmissions in combination with privacy concerns make enforcement costly and difficult. A broad interpretation exposes millions of filesharers to potentially crushing statutory damages.

The drafters expressly intended to broaden the reach of the "publish" and "vend" rights. The reason for the change in terminology was to avoid some of the confusing jurisprudential baggage that had formed around the meaning of "publication.” The courts remain divided over the proper interpretation of the distribution right in file-sharing cases. ${ }^{47}$ The US Copyright Office has endorsed the broader interpretation based on the legislative history as well as conformance with international treaty obligations. ${ }^{48}$ In any case, the fact that a forensic expert hired by the copyright owner was able to find the copyrighted work in a file-sharing folder controlled by the defendant relatively easily_by, for example, searching for a work's title or artist on widely available search engines - is sufficient to establish that it was more probable than not that the work was distributed.

Congress carved out an important limitation on the exclusive right to distribute. The "first sale doctrine" provides that "the owner of a particular copy or phonorecord lawfully made under this title, or any person authorized by such owner, is entitled, without the authority of the copyright owner, to sell or otherwise dispose of the possession of that copy or phonorecord." 49 This doctrine has a long pedigree. ${ }^{50}$ The purchaser/recipient of an authorized copy may resell, lease, donate, or dispose of it without restriction, but may not copy it. In response to the availability of home copying technologies, Congress limited the first sale doctrine by prohibiting the rental of phonorecords and computer programs for profit, fearing that the primary effect of such rentals was to encourage piracy. ${ }^{51}$

\footnotetext{
${ }^{46}$ See 17 U.S.C. §602(a)(3) (exceptions for government use (but not including schools), personal copies for private use, and scholarly, education, or religious purposes (nut not more than five copies). Section 602(b) prohibits importation of infringing copies.

${ }^{47}$ Compare Diversey v. Schmidly, 738 F.3d 1196, 1202 n.7 (10th Cir. 2013) with London-Sire Records, Inc. v. Doe, 542 F. Supp. 2d 153 (D. Mass. 2008).

${ }^{48}$ See U.S. Copyright Office, The Making Available Right in the United States: A Report of the Register (Feb. 2016); Peter S. Menell, In Search of Copyright's Lost Ark: Interpreting the Right to Distribute in the Internet Age, 59 J. COPYRIGHT SOC’Y U.S.A. 1 (2011).

4917 U.S.C. $\S 109(a)$.

${ }^{50}$ See Kirtsaeng v. John Wiley \& Sons, Inc., 133 S.Ct. 1351 (2013); Bobbs-Merrill Co. v. Straus, 210 U.S. 339 (1908).

${ }^{51}$ See §109(b); Ryan Vacca, Expanding Preferential Treatment Under the Record Rental Amendment Beyond the Music Industry, 11 LEWIS \& CLARK L. REV. 605, 612-14 (2007).
} 
The emergence of 3D printing opens up the need for a new copyright doctrine paralleling patent law's repair and reconstruction doctrine. ${ }^{52}$ Under the exhaustion principle, the first unrestricted sale of a patented product exhausts the patentee's control over that product and it can be resold and repaired without implicating the patent owner's rights. Nonetheless, courts have longrecognized that purchasers of patented products have an inherent right to repair such goods, although they may not reconstruct the patented technology. ${ }^{53}$

Suppose a consumer purchases a copyrighted useful article and some component breaks. Should that consumer be able to invoke the first-sale doctrine to justify scanning the broken component so as to print a replacement? Alternatively, would that consumer be justified under a hybrid first-sale/fair use principle, in accessing a copyrighted CAD file for purposes of effecting a repair? Would a vendor of the copyrighted useful article be able to override such acts through contractual restrictions? ${ }^{54}$ Just as the emergence of licensed computer software created the conditions for development of the copyright misuse doctrine, ${ }^{55}$ the emergence of 3D printing hastens the development of a copyright repair doctrine. The brave new world of 3D printing opens up these and related questions. ${ }^{56}$

\section{Public Display Right}

The Copyright Act grants owners of "pictorial, graphic, or sculptural works" the exclusive right to display such works publicly. ${ }^{57}$ Section 101 defines "display" broadly: "to show a copy of [the work], either directly or by means of a film, slide, television image, or any other device or process or, in the case of a motion picture or other audiovisual work, to show individual images nonsequentially.” Users posting images of copyrighted products on file-sharing web sites, or even social media accounts, display a copy of the product by means of a computer.

Publicly displaying a work includes "transmit[ting] or otherwise communicat[ing] a ... display of the work to a place [open to the public or where a substantial number of persons outside of a normal circle of a family and its social acquaintances is gathered] or to the public, by means of any device or process, whether the members of the public capable of receiving the . . . display receive it in the same place or in separate places and at the same time or at different times." 58

Posting images on a publicly accessible website constitutes a public display of the copyrighted work. As with the reproduction and adaptation rights, fair use may limit liability under the public display right. Furthermore, section 113(c) permits owners of lawfully reproduced useful articles "that have been offered for sale or other distribution to the public" to make, distribute, or display

\footnotetext{
${ }^{52}$ See Kelsey B. Wilbanks, Comment, The Challenges of $3 D$ Printing to the Repair-Reconstruction Doctrine in Patent Law, 20 GEO. MASON L. REV. 1147 (2013).

53 See 5 Donald S. Chisum, Chisum on PATENTS §16.03[3], at 16-449 to -450 (2012); Hewlett-Packard Co. v. Repeat-O-Type Stencil Mfg. Co., 123 F.3d 1445 (Fed. Cir. 1997); Aro Mfg. Co. v. Convertible Top Replacement Co., 365 U.S. 336 (1961).

${ }^{54}$ Compare Vernor v. Autodesk Inc., 621 F.3d 1102 (9th Cir. 2010) with Softman Products Co., LLC v. Adobe Systems, Inc., 171 F. Supp.2d 1075 (C.D. Cal. 2001); see generally U.S. DEPARTMENT OF COMMERCE INTERNET Policy TAsk Force, White PaPer on RemiXes, First Sale, and Statutory Damages (Jan. 2016).

${ }^{55}$ See Lasercomb America, Inc. v. Reynolds, 911 F.2d 970 (4th Cir. 1990); Xavier Fellmeth, Copyright Misuse and the Limits of the Intellectual Property Monopoly, 6 J. INTELL. Prop. L. 1, 24 (1998).

${ }^{56}$ Cf. Aaron Perzanowski \& Jason Schultz, Digital Exhaustion, 58 UCLA L. REv. 889, 913-915 (2011).

${ }^{57} 17$ U.S.C. $\$ 106(5)$.

5817 U.S.C. §101(2) (definition of “publicly”).
} 
"pictures or photographs of such articles in connection with advertisements or commentaries related to the distribution or display of such articles, or in connection with news reports."

\section{Indirect Liability}

The potential liability of enterprises higher in the copyright enforcement pyramid — such as search engines, CAD file-sharing services, 3D printing shops, and 3D printer manufacturersstems less from their direct infringement than from indirect liability doctrines. As noted above, some of these actors could face direct liability for reproducing, adapting, distributing, or publicly displaying copyrighted works. 3D printing file-sharing services, such as Thingiverse or Pinshape, allow users to post CAD files online for others to download and use to print objects. More significantly, however, they are attractive targets because of their ability to contribute to, vicariously benefit from, and induce copyright infringement on a broader scale due to their upstream location in the digital enforcement pyramid. Moreover, these actors are likely to facilitate a broader range and number of infringing acts and have deeper pockets than individual end-users. Thus as in the music file-sharing context, copyright owners of CAD files and underlying 3D works would prefer to be able to stanch infringing activity at this higher level. Nonetheless, US copyright law has various doctrines and safe harbors that limit or shield upstream actors from liability.

This section surveys the indirect copyright liability landscape. Section 1 sketches the historical development and contours of indirect copyright liability. Section 2 examines the Sony staple article of commerce, which insulates providers of products or services that are capable of substantial noninfringing use from liability. Section 3 discusses the online service provider safe harbors that insulate Internet enterprises from indirect copyright liability.

\section{Indirect Liability Doctrines}

From its origins in 1790 to the present, the US copyright legislation has provided only a general statement outlining the scope of copyright liability. Even the modern statute states tersely that “[s]ubject to sections 107 through 122, the owner of copyright under this title has the exclusive rights to do and to authorize any of the following [reproduce, adapt, distribute, publicly perform, publicly display, digitally perform]." 59 The statutory text only obliquely refers to indirect liability. ${ }^{60}$

Building on the English common law tradition, American courts have long looked to tort law principles to delineate the contours of copyright liability. ${ }^{61}$ By the mid-twentieth century, US copyright law clearly established a broad panoply of indirect copyright liability doctrines: respondeat superior, vicarious liability, contributory liability, and inducement liability.

\footnotetext{
5917 U.S.C. $§ 106$.

60 The legislative history of the Copyright Act of 1976 states that "Use of the phrase "to authorize" is intended to avoid any questions as to the liability of contributory infringers. For example, a person who lawfully acquires an authorized copy of a motion picture would be an infringer if he or she engages in the business of renting it to others for purposes of unauthorized public performance.” H.R. REP. No. 94-1478 at 61 (emphasis added).

${ }^{61}$ See Lawrence v. Dana, 15 F. Cas. 26, 61 (C.C. Mass. 1869) ("Rights secured by copyright are property within the meaning of the law of copyright, and whoever invades that property beyond the privilege conceded to subsequent authors commits a tort . . . ”); J. F. CLERK \& W. H. B. LiNDELL, THE LAW OF TORTS 587 (2d ed. 1896) (featuring a copyright chapter in an early tort law treatise); see generally Peter S. Menell \& David Nimmer, Unwinding Sony, 95 CALIF. L. REV. 941 (2007).
} 
Respondeat Superior. Toward the end of the nineteenth century, a court held a newspaper liable for publishing a copyrighted map notwithstanding that the work was inserted without the newspaper's knowledge or consent. ${ }^{62}$ Theatre owners and music stores bore responsibility for copyright infringements by those who performed copyrighted musical compositions without authorization, ${ }^{63}$ even if done against the employer's orders. ${ }^{64}$

Vicarious Liability. The doctrine of vicarious liability arose to deal with the situation in which third parties exercise control over or motivate the actions of others and stand to benefit from such activities. ${ }^{65}$ As described by the Second Circuit, "When the right and ability to supervise coalesce with an obvious and direct financial interest in the exploitation of copyrighted materials-even in the absence of actual knowledge that the copyright monopoly is being impaired - the purposes of copyright law may be best effectuated by the imposition of liability upon the beneficiary of that exploitation." 66

Contributory and Inducement Liability. The Second Circuit has delineated the standards for contributory copyright liability as follows: “one who, with knowledge of the infringing activity, induces, causes or materially contributes to the infringing conduct of another, may be held liable as a 'contributory' infringer." 67 Thus, in Elektra Records v. Gem Elec. Distribs., ${ }^{68}$ an electronics store which sold blank tapes and made available both pre-recorded tapes of copyrighted works and a high speed, coin-operated "Make-A-Tape" system was held contributorily liable for the infringing activities of its customers.

\section{Jurisprudential Limitations on Indirect Liability: The Staple Article of Commerce Doctrine}

The Supreme Court established a significant limitation on indirect copyright liability in Sony Corporation of America v. Universal City Studios, Inc. ${ }^{69}$ Following the introduction of videocassette recording technology by Sony in 1976, motion picture studios alleged that Sony contributorily infringed the studios' copyrights by providing the means (the Betamax video cassette recorder) by which Sony customers directly infringed film and television program copyrights. The case raised complex issues surrounding indirect liability (does an upstream device manufacturer bear responsibility for infringing acts of device users?) and direct liability (is timeshifting or archiving of television broadcasts (along with the advertisements that provide the principal revenue stream to broadcasters) fair use?).

Although holding that time-shifting of programming was fair use, the Court failed to resolve whether making archival copies constituted fair use. This necessitated addressing the scope of indirect liability. Drawing from patent law, ${ }^{70}$ the Supreme Court stated that "the sale of copying

\footnotetext{
${ }^{62}$ McDonald v. Hearst, 95 F. 656 (D.C. Cal. 1899); see also Leon et al. v. Pacific Tel. \& Tel. Co., 91 F.2d 484, 487 (9th Cir. 1937) (imposing liability for compiling a directory); West Pub. Co. v. Lawyers' Co-operative Pub. Co., 79 F. 756 (2d Cir. 1897) (imposing liability for compiling law digest).

${ }^{63}$ See Harms v. Cohen, 279 F. 276 (E.D. Pa. 1922); M. Witmark \& Sons v. Pastime Amusement Co., 298 F. 470, 475 (E.D.S.C. 1924), aff'd mem., 2 F.2d 1020 (4th Cir. 1924); Shapiro, Bernstein \& Co. v. Veltin, 47 F. Supp. 648, 649 (W.D. La. 1942); Bourne v. Fouche, 238 F. Supp. 745, 747 (E.D.S.C. 1965).

${ }^{64}$ See M. Witmark \& Sons v. Calloway, 22 F.2d 412 (E.D. Tenn. 1927).

65 See RestatemENT (SECOND) OF AGENCY §2 (1958).

${ }^{66}$ Shapiro, Bernstein \& Co. v. H.L. Green Co., 316 F.2d 304 (2d Cir. 1963).

${ }^{67}$ Gershwin Publ'g Corp. v. Columbia Artists Mgmt, 443 F.2d 1159, 1162 (2d Cir. 1971).

${ }^{68} 360$ F. Supp. 821 (E.D.N.Y. 1973).

69464 U.S. 417 (1984).

${ }^{70}$ See 35 U.S.C. §271(c).
} 
equipment, like the sale of other articles of commerce, does not constitute contributory infringement if the product is widely used for legitimate, unobjectionable purposes. Indeed, it need merely be capable of substantial noninfringing uses."71

This doctrine is of particular importance to manufacturers and distributors of 3D printers. Although some consumers directly infringe when they print, 3D printers are capable of substantial non-infringing uses. They are capable of producing uncopyrightable useful articles, such as prostheses, tools, and replacement parts. Moreover, there is an extensive community of designers who freely share their designs and authorize modification and printing of the products. ${ }^{72}$ These uses do not even take into account whether printing copyrightable products constitutes fair use.

There is, however, an exception to Sony's substantial non-infringing use doctrine. In MetroGoldwyn-Mayer Studios Inc. v. Grokster, Ltd., ${ }^{73}$ the Supreme Court recognized that even the distributor of a product or service that is capable of substantial non-infringing use could be liable for inducing infringement if it "distributes a device with the object of promoting its use to infringe copyright, as shown by clear expression or other affirmative steps taken to foster infringement."74 To steer clear of Grokster's inducement standard, 3D printer manufacturers should avoid advertising infringing uses or works and instead promote the multitude of available non-infringing uses.

\section{Statutory Limitations on Indirect Copyright Liability: The Online Service Provider Safe Harbor}

As the Internet emerged as a major communications and commercial medium in the mid1990s, the new breed of commercial enterprises providing online access faced the specter of crushing indirect copyright liability as a result of infringing online activity by their users. Congress confronted this threat by establishing the online service provider (OSP) safe harbor provisions of the Digital Millennium Copyright Act (DMCA). ${ }^{75}$

Section 512(c), which deals with "information residing on systems or networks at [the] direction of users," is of most relevance to the emerging 3D printing industry. ${ }^{76}$ This safe harbor affords websites hosting user-generated content, such as YouTube, Shapeways, Thingiverse, and Pinshape, with immunity from monetary liability for infringing acts of file uploaders and downloaders. To qualify for the safe harbor, storage websites must comply with three general threshold conditions as well as several storage-related conditions.

To comply with the general threshold conditions, the OSP must: (i) adopt, implement, and inform its subscribers of its policy for terminating service to users who are repeat copyright infringers; (ii) adopt standard technical measures used by copyright owners to identify and protect copyrighted works; and (iii) designate an agent to receive notification of claimed infringement from copyright owners and register that agent with the Copyright Office.

\footnotetext{
71464 U.S. at 442.

${ }^{72}$ Charles W. Finocchiaro, Note, Personal Factory or Catalyst for Piracy? The Hype, Hysteria, and hard Realities of Consumer 3-D Printing, 31 CARDOZO ARTs \& ENT. L.J. 473, 495 (2013).

73545 U.S. 913 (2005).

${ }^{74}$ Metro-Goldwyn-Mayer Studios Inc. v. Grokster, Ltd., 545 U.S. 913, 936-937 (2005). This doctrine has since been applied in Columbia Pictures Industries, Inc. v. Fung, 710 F.3d 1020 (2013), to hold a search website operator liable for affirmative actions to induce copyright infringement.

75 See 17 U.S.C. $§ 512$.

76 Other OSP safe harbors immunize transmission and routing of information, caching (making temporary copies on their systems; and linking to infringing material.
} 
To comply with the additional requirements of §512(c), the OSP must not have actual knowledge of the infringing conduct ${ }^{77}$ nor be "aware of facts or circumstances from which infringing activity is apparent." ${ }^{78}$ Courts interpreting the knowledge standard have set the bar fairly high. Both the Second and Ninth Circuits have rejected a standard that removes the safe-harbor if the service provider has generalized knowledge of infringement. ${ }^{79}$ Instead, these courts require providers to know or be aware of facts or circumstances indicating "specific and identifiable instances of infringement." ${ }^{80}$ In addition, OSPs must expeditiously remove allegedly infringing content after being notified by a copyright owner. ${ }^{81}$ OSPs satisfying these requirements are shielded from monetary relief and most forms of equitable relief. Importantly, the statute exempts OSPs from any affirmative duty to monitor activity on their website. ${ }^{82}$

CAD file-sharing sites are similar to other file-sharing websites that receive DMCA immunity from indirect copyright liability. Like YouTube, they should be able to stay within the protection of the $\S 512$ (c) safe harbor even though they are generally aware that some of the uploaded files infringe copyrighted works. They must, however, designate an agent to receive takedown notices, expeditiously respond to such notices, and create and implement policies for terminating repeat infringers. ${ }^{83}$ A survey of $3 \mathrm{D}$ printing file-sharing sites indicates they are attempting to take advantage of the safe-harbors. ${ }^{84}$

Although CAD file-sharing sites can qualify for the OSP safe harbor, they might still face liability for inducing copyright infringement. There is a split in the courts as to whether the DMCA insulates OSPs from inducement claims. ${ }^{85}$ As explained earlier with respect to 3D printer manufacturers, these sites can steer clear of inducement exposure by avoiding any language or acts that encourage copyright infringement and instead promote the non-infringing uses of their website, such as to disseminate non-infringing CAD files. The Fung case ${ }^{86}$ highlights practices to be avoided.

\footnotetext{
7717 U.S.C. $\S 512(\mathrm{c})(1)(\mathrm{A})(\mathrm{i})$.

${ }^{78} 17$ U.S.C. §512(c)(1)(A)(ii). This requirement is referred to as the "red flag" provision. If the red flag is waving, the OSP must promptly remove the infringing work.

${ }^{79}$ See Viacom International, Inc. v. YouTube, Inc., 676 F.3d 19, 30-32 (2nd Cir. 2012); UMG Recordings, Inc. v. Shelter Capital Partners LLC, 718 F.3d 1006, 1020-1023 (9th Cir. 2013).

${ }^{80}$ Viacom, 676 F.3d at 32; UMG Recordings, 718 F.3d at 1021.

81 17 U.S.C. §512(c)(1)(A)(iii) - (c)(3). The DMCA requires the OSP to notify the user promptly of the takedown and inform the uploader of the right to submit a counter-notification requesting that the material be restored. 17 U.S.C. §512(g). If the user provides a counter-notification contesting the takedown request, the OSP is required to replace the disputed content unless the copyright owner sues the uploader within 14 days of the counter notification. If the copyright owner does not file suit against the uploader within a designated period, the OSP must restore the material. It may replace the disputed material after 10 days if the copyright owner has not filed a lawsuit but is required to restore it within 14 business days of the counter notification if no lawsuit is filed against the uploader.

8217 U.S.C. §512(m).

${ }^{83}$ Michael Weinberg, What Lawyers Might Like to Know About 3D Printing and the Law, 6:4 LANDSLIDE 42, 44 (2014).

84 See e.g., Shapeways Content Policy and Notice Takedown Procedure at http://www.shapeways.com/legal/content_policy; Pinshape Copyright and DMCA Policy at https://pinshape.com/copyright; Thingiverse Intellectual Property Policy at http://www.thingiverse.com/legal/ippolicy; Bryan J. Vogel, The Maker Community and IP: Lessons from the Digital Millennium Copyright Act, Inside3DP (Nov. 17, 2014, 12:06 AM), http://www.inside3dp.com/maker-community-ip-lessons-digital-millenium-copyrightact/.

${ }^{85}$ See John Blevins, Uncertainty as Enforcement Mechanism: The New Expansion of Secondary Copyright Liability to Internet Platforms, 34 Cardozo L. Rev. 1821, 1852-53 (2013).

${ }^{86}$ See Columbia Pictures Industries, Inc. v. Fung, 710 F.3d 1020 (2013).
} 
The DMCA affords users of storage websites a cause of action against over-zealous copyright owners who make dubious takedown requests. ${ }^{87}$ Section 512(f) imposes liability on anyone who "knowingly materially misrepresents . . . that material or activity is infringing." ${ }^{8}$ Copyright owners making takedown requests must consider whether an allegedly infringing work would qualify for the fair use privilege. ${ }^{89}$

The DMCA places the burden of policing infringement on copyright owners. Yet copyright owners can effectively impose substantial costs on OSPs by issuing numerous takedown requests. As more sites emerge and more designs are uploaded, policing becomes an increasingly difficult task. Film and music copyright owners alleviated some of this burden by collaborating with filesharing services to create and implement automated filtering technologies. ${ }^{90}$ Such collaborations may prove useful in the design file-sharing arena as 3D printing expands.

\section{Business Strategies}

Although design copyright owners may have legal grounds to enforce their copyrights against infringers in the emerging 3D printing field, the costs of doing so are significant and the efficacy is questionable. The major music and film companies abandoned large-scale direct enforcement against end-users after that approach proved counterproductive ${ }^{91}$ and have focused their attention on selective enforcement ${ }^{92}$ and making their works more widely available through innovative, user-friendly, and better priced licensed channels, such as subscription and streaming services and closer working relationships with YouTube.

The 3D printing revolution brings a range of distinctive business strategy and public policy issues into play. Product manufacturing and design businesses affected by 3D printing are highly heterogeneous. Sophisticated, mission-sensitive equipment manufacturers and parts suppliers have very different concerns than fine art sculptors and toy and apparel makers. Some of these businesses see tremendous benefits from entering the 3D printing arena as a means of better meeting customer demand for customized products and reducing inventory, manufacturing, and distribution costs. Yet these same companies are prone to competition and reputational harm from new entities entering after-markets for replacement parts, customization, and repair services. In addition, their business reputation can suffer to the extent consumers are confused as to the source and quality of replacement parts and repair services. Public safety can also be undermined to the extent lower quality and confusingly sourced replacement parts enter the market. Innovation and

\footnotetext{
${ }^{87}$ See Wendy Seltzer, Free Speech Unmoored in Copyright's Safe Harbor: Chilling Effects of the DMCA on the First Amendment, 24 HARV. J. L. \& TECH. 171, 178 (2010).

8817 U.S.C. $\S 512(\mathrm{f})(1)$.

${ }^{89}$ See Lenz v. Universal Music Corp., 815 F.3d 1145, 1153 (9th Cir. 2015).

${ }^{90}$ See Peter S. Menell, Design for Symbiosis: Promoting More Harmonious Paths for Technological Innovators and Expressive Creators in the Internet Age, 55 COMM. OF THE ACM, No. 5, 30-32 (May 2012).

${ }^{91}$ See Sarah McBride \& Ethan Smith, Music Industry to Abandon Mass Suits, Wall StreEt Journal (Dec. 19, 2008). Some independent film companies, notably pornography enterprises, continue to sue direct infringers and filesharers. See Matthew Sag, Copyright Trolling, an Empirical Study, 100 IowA L. REV. 1105 (2015).

${ }^{92}$ The major music and film industries have continued to pursue OSPs that allegedly induce widespread infringing activities. See, e.g., Stuart Dredge, 'Popcorn Time of music' Aurous shut down before it ever really started, THE GUARDIAN (Dec. 10, 2015), https://www.theguardian.com/technology/2015/dec/10/popcorn-time-music-aurous-shutdown; Ernesto, MPAA: We Shut Down YTS/YIFY and Popcorn Time, TORRENTFrEAK (Nov. 4, 2015), https://torrentfreak.com/mpaa-we-shut-down-ytsyify-and-popcorn-time-151103/; Columbia Pictures Industries, Inc. v. Fung, 710 F.3d 1020 (2013); Arista Records LLC v. Lime Group LLC, 715 F. Supp. 2d 481 (2010) (shutting down the file-sharing network Limewire).
} 
consumer interests, however, can suffer to the extent that original manufacturing companies block legitimate after-market competition for replacement parts, repair services, and other secondary markets. $^{93}$

This section explores two sets of business strategies that turn on or interact with copyright law. Section A examines the use of encryption or digital rights management strategies to reduce the risks of CAD file piracy. Section B examines the use of licensing agreements to control the distribution of designs.

\section{A. Digital Rights Management}

Like other software products, CAD files can be distributed with encryption or technological protection measures (TPMs) that prevent or limit their reproduction without authorization of the manufacturer. The DMCA established a special "para-copyright" regime that prohibits circumvention of TPMs. ${ }^{94}$ These provisions go beyond traditional copyright protection in that they prohibit specific acts, such as decrypting TPMs, trafficking in anti-circumvention devices such as encryption keys, or removing copyright management information, whether or not such acts result in copyright infringement. Content industries advocated for these protections in the belief that they could prevent online piracy through the use of digital rights management (DRM) technologies. The anti-circumvention provisions aim for significant deterrent civil and criminal remedies. ${ }^{95}$

The efficacy of DRM for product and design companies will depend on the nature of their products and limitations on enforcement of anti-circumvention provisions. DRM works most effectively for works, like computer software code, that cannot be gleaned merely from examining a product. This strategy is deployed with great success in the video game marketplace. ${ }^{96}$ Although consumers (and competitors) can view the screen outputs of video games, they cannot see (or reproduce) the computer code that generates the audiovisual outputs without decrypting the computer code. Similarly, CAD files protected by DRM can be controlled so as to prevent access to the underlying code. The files can be designed to only work with authorized printers. They can also limit the number of copies made or the duration of access to the files' functionality. Alternatively, instead of permitting consumers to download a CAD file, modify it, and print it, content owners could stream the CAD file to consumers' networked 3D printers. ${ }^{97}$ For consumers who simply want an error-free copy of a product and do not wish to modify it, streaming may perfectly suit their needs.

Unlike video games, however, the full "output" of the CAD file-a three-dimensional printed object-can be directly perceived, studied, scanned, and reproduced. Thus, the degree of protection available from DRM is limited. Nonetheless, to the extent that the object can be only imperfectly reproduced from the physical object-like a video capture of a DVD-and high precision is important to consumers, DRM can be somewhat effective. ${ }^{98}$

The DMCA anti-circumvention regime will also be of only limited effectiveness as an antipiracy protection due to several exceptions within the statutory regime. The DMCA expressly

\footnotetext{
93 See Severin Borenstein et al., Antitrust Policy in Aftermarkets, 63 ANTITRUST L.J. 455 (1995).

9417 U.S.C. $\S \S 1201-05$.

9517 U.S.C. §§1203-04.

96 See Jennifer Miller, Note, The Battle Over "Bots": Anti-Circumvention, the DMCA, and "Cheating” at World of Warcraft, 80 U. CIN. L. REV. 653, 683 (2011).

97 Deven R. Desai, The New Steam: On Digitization, Decentralization, and Disruption, 65 HASTINGS L.J. 1469,1480 (2014).

${ }^{98}$ See id.
} 
authorizes reverse engineering of computer programs for the "sole purpose of identifying and analyzing those elements of the program that are necessary to achieve interoperability of an independently created computer program." 99 In addition, as a safety valve to prevent undue impingement of fair use of copyrighted works and other public policy purposes, the DMCA contains various exemptions for law enforcement activities, radio and television broadcasters, libraries, encryption researchers, filtering of content to prevent access by minors, and protection for personally identifying information. ${ }^{100}$ It also authorizes the Copyright Office to establish specific exemptions for any classes of copyrighted works where persons making non-infringing uses are likely to be adversely affected by the anti-circumvention ban. ${ }^{101}$ The Copyright Office issues new exemptions on a triennial basis.

Of particular relevance to 3D printing, the Copyright Office and the courts have sought to prevent the anti-circumvention provisions from being used to control after-markets lacking a legitimate nexus to the protection of copyrightable expression. ${ }^{102}$ Furthermore, the copyright misuse doctrine could come into play. ${ }^{103}$ These considerations limit the use of the Copyright Act's anti-circumvention provisions to control products for functional designs that do not have separable copyrightable expression. Nonetheless, product manufacturers could still use DRM to control reproduction and access to their design information. They would not, however, be able to use the Copyright Act's anti-circumvention provisions to prevent decryption, trafficking in decryption information, or efforts to alter copyright management information. And they might encounter antitrust scrutiny.

\section{B. Licensing}

The music and film industries ramped up their use of subscription, low-cost download, and other licensed distribution channels to attract consumers and compete without unauthorized distributors of their works. ${ }^{104}$ Analogously, product manufacturers and designers can deploy licensing strategies to develop and control markets for 3D printing. ${ }^{105}$ Consumers may want the assurance that they are receiving authentic products that meet the product manufacturer's specifications and carry the manufacturer's warranty. Product designers and repair service businesses might value licenses, technical assistance, and copyright permission to reproduce, adapt, and distribute designs.

The toy company Hasbro, for example, has partnered with 3D Systems to bring copyrighted toy designs such as Mr. Potato Head ${ }^{\circledR}$, Tonka ${ }^{\circledR}$ trucks, and Transformers ${ }^{\circledR}$ to consumers through 3D print markets. ${ }^{106}$ Similarly, Hasbro has partnered with Shapeways so users can create

\footnotetext{
9917 U.S.C. $\S 1201(\mathrm{f})(1)$.

10017 U.S.C. $\S \S 1201(\mathrm{~d}),(\mathrm{e}),(\mathrm{h}),(\mathrm{i})$.

101 See Arielle Singh, Agency Regulation in Copyright Law: Rulemaking under the DMCA and Its Broader Implications, 26 BERKELEY TECH. L.J. 527 (2011).

${ }^{102}$ See Exemption to Prohibition on Circumvention of Copyright Protection Systems for Access Control Technologies, 80 FED. REG. 65944 (Oct. 27, 2015); Lexmark Int’l, Inc. v. Static Control Components, Inc., 387 F.3d 522 (6th Cir. 2004); Chamberlain Group, Inc. v. Skylink Tech., Inc., 381 F.3d 1178 (Fed. Cir. 2004) cf. Dan I. Burk, AntiCircumvention Misuse, 50 UCLA L. REV. 1095 (2003).

103 See Brett Frishmann \& Dan Moylan, The Evolving Common Law Doctrine of Copyright Misuse: A Unified Theory and Its Application to Software, 15 BERKELEY TECH. L.J. 865 (2000).

104 See Menell, supra note 32, at 366-709.

105 See Desai \& Magliocca, supra note 9, at 1705 (2014) (discussing the iTunes and Amazon's eBook platform as models for 3D printing markets); Dasari, supra note 37, at 316.

106 See John Hornick, IP Licensing in a 3D Printed World, 50 LEs NouVELLES 95, 98 (2015).
} 
customized versions of Hasbro products. ${ }^{107}$ Shapeways then 3D prints the item and sends it to the end users.

Licensing strategies involve context-specific trade-offs for the range of businesses affected by 3D printing technology. Moreover, efforts to collude with potential competitors in horizontal and related markets could run afoul of antitrust laws.

Copyright law imposes several potential constraints on licensing strategies. US law treats contracts as a species of state law. Under the US Constitution, state laws cannot interfere or conflict with federal law. ${ }^{108}$ The Copyright Act overrides all "legal or equitable rights that are equivalent to any of the exclusive rights within the general scope of copyright as specified by section 106."109 US courts are split over whether copyright owners can restrict the fair use privilege and other limitations on copyright protection through licensing restrictions. ${ }^{110}$ They are also split over whether parties can contract around the first sale doctrine. ${ }^{111}$ In addition, the copyright misuse doctrine limits the ability of licensors to leverage copyright protection through licensing to limit competition and innovation.

\section{Conclusions}

Although bearing some similarities to other disruptive technologies, 3D printing poses a range of new opportunities and challenges for product manufacturing and design businesses, online service providers, consumers, designers, and inventors. US copyright law's general provisions and principles frame the governance landscape, but the ultimate governance regime will depend upon the business strategies that copyright owners and disruptive businesses pursue, the extent to which courts adapt copyright doctrines to new and unforeseen challenges, and the Copyright Office's exemptions under the DMCA's anti-circumvention provisions.

\footnotetext{
107 See id.

108 See U.S. CONST., ART. VI, CL. 2.

${ }^{109}$ See 17 U.S.C. $\$ 301(a)$.

${ }^{110}$ Compare Vault Inc. v. Quaid Corp., 847 F.2d 255 (5th Cir. 1988) with Davidson \& Assocs. v. Jung, 422 F.3d 630 (8th Cir. 2005) and Bowers v. Baystate Technologies, 320 F.3d 1317 (Fed. Cir. 2003); see generally MARGARET JANE RAdin, Boilerplate: The Fine Print, VANishing Rights, AND the Rule of LAW (2014).

${ }^{111}$ Compare Kirtsaeng v. John Wiley \& Sons, Inc., 133 S.Ct. 1351 (2013) and UMG Recordings, Inc. v. Augusto, 628 F.3d 1175 (9th Cir. 2011) with Vernor v. Autodesk Inc., 621 F.3d 1102 (9th Cir. 2010) and Capitol Records, LLC v. ReDigi, Inc., 934 F. Supp. 2d 640 (S.D.N.Y. 2013); see generally Aaron Perzanowski \& Jason Schultz, Reconciling Intellectual and Personal Property, 90 NoTRE DAME L. REV. 1211 (2015).
} 